\title{
TOTAL NITROGEN AND AVAILABLE PHOSPHORUS DYNAMICS IN SOILS REGENERATING FROM DEGRADED ABANDONED RUBBER PLANTATION IN OROGUN AREA OF THE RAINFOREST ZONE OF SOUTHERN NIGERIA ICHIKOGU, V.I. \\ DOI: $\underline{\text { http://dx.doi.org/10.4314/ejesm.v5i1.11 }}$
}

\author{
Received $9^{\text {th }}$ November 2011; accepted $15^{\text {th }}$ February 2012
}

\begin{abstract}
Total nitrogen and available phosphorus concentration of soils in three secondary forest fields aged 1, 5 and 10 years of age regenerating from degraded abandoned rubber plantation (Hevea brasiliensis) and a mature forest in the west African Rainforest belt in southern Nigeria were investigated in order to determine the trend of change in the properties of soil in secondary forest during the course of forest restoration from degraded deserted rubber plantation (Hevea brasiliensis). There was a continuous increase in the concentration of total nitrogen in the soil (both topsoil and subsoil). The concentrations of total nitrogen and available phosphorus in the topsoil are higher than the subsoil. The concentration of available phosphorus during the first five years of secondary forest regeneration increased, after which their values declined by the tenth year in both the topsoil and the subsoil. Should this trend of decline in the concentration of phosphorus continue phosphorus may become a limiting factor to plant growth the older the secondary forests become.
\end{abstract}

Keywords: Total nitrogen, Available phosphorus, Rubber plantation, Degraded, Orogun, Southern Nigeria.

\section{INTRODUCTION}

Previous studies on the changes in total nitrogen and available phosphorus of secondary forest soils in tropical Africa and Asia have focused on secondary forests regenerating from shifting cultivation agriculture of food crops (Nye 1958, Greenland 1959, Nye and Greenland 1960 and 1964, Aweto 1981, Toky and Ramakrishnan 1983, Owusu-Seykyere 2006). In tropical Amazon the focus is on the dynamics of soil nutrient in secondary forests regenerating from degraded pasture (Feldspauch et al. 2004, 2005 and 2010). These studies disclosed that total nitrogen and available phosphorus in soil are likely to change at different phases of development in secondary forests and may be affected by amount of disturbance, nature of disturbance, age of fallow and the floristic composition of the secondary forest.

One obvious outcome of these research works is that none of these studies paid attention to the changes in soil total nitrogen and available phosphorus in secondary forest regenerating from degraded abandoned rubber

clo Professor A.O. Aweto, Department of Geography, University of Ibadan Oyo State Nigeria.

Email: victorichikogu@yahoo.com plantation which is one of the major types of secondary forest in South-South Nigeria today. Knowledge of such changes is of direct relevance to the problem of soil fertility rejuvenation in secondary forest regenerating on degraded rubber plantation. A thorough understanding of this changes is not only necessary for devising more intensive systems of agriculture on this type of secondary forest but will help to avert costly mistakes when other systems of agriculture are introduced to replace this type of secondary forest.

\section{Study Area}

The study area- a distance of about 50 kilometers from Warri in Delta State Nigeria, is located between latitude $5^{0} 20^{\prime} \mathrm{N}$ and $5^{0} 366^{\prime} \mathrm{N}$ and between longitude $5^{0} 30^{\prime} \mathrm{E}$ and $6^{\circ} 06^{\prime} \mathrm{E}$ (Fig. 1).The climate is warm and humid throughout the year with mean annual rainfall of about 2000 to $2500 \mathrm{~mm}$. Temperatures of the study area are high throughout the year with no sharp seasonal variations and mean annual range of $2^{0} \mathrm{C}$ (Efe 2006). The natural vegetation is the tropical lowland rainforest of the moist evergreen type (Aweto 2002), 
patches of which still exist around swampy areas adjacent the river valley and on well drained sites they are confined to sacred groves preserved for ceremonial purposes. Due to the prevalence of agriculture, fuel wood exploitation and other anthropogenic disturbances most of the original forest has been destroyed and the landscape replaced by secondary re-growth fallow in different stages of succession. The landscape is low-lying deltaic plain of southern Nigeria and is a featureless plain with vast expanses of almost flat surfaces, with land elevation of less than 25 meters above sea level. The soils are sandy, deeply weathered ferrallitic soils (Oxisols). They were formed from unconsolidated sediments of sandstone parent material and have been leached severely.

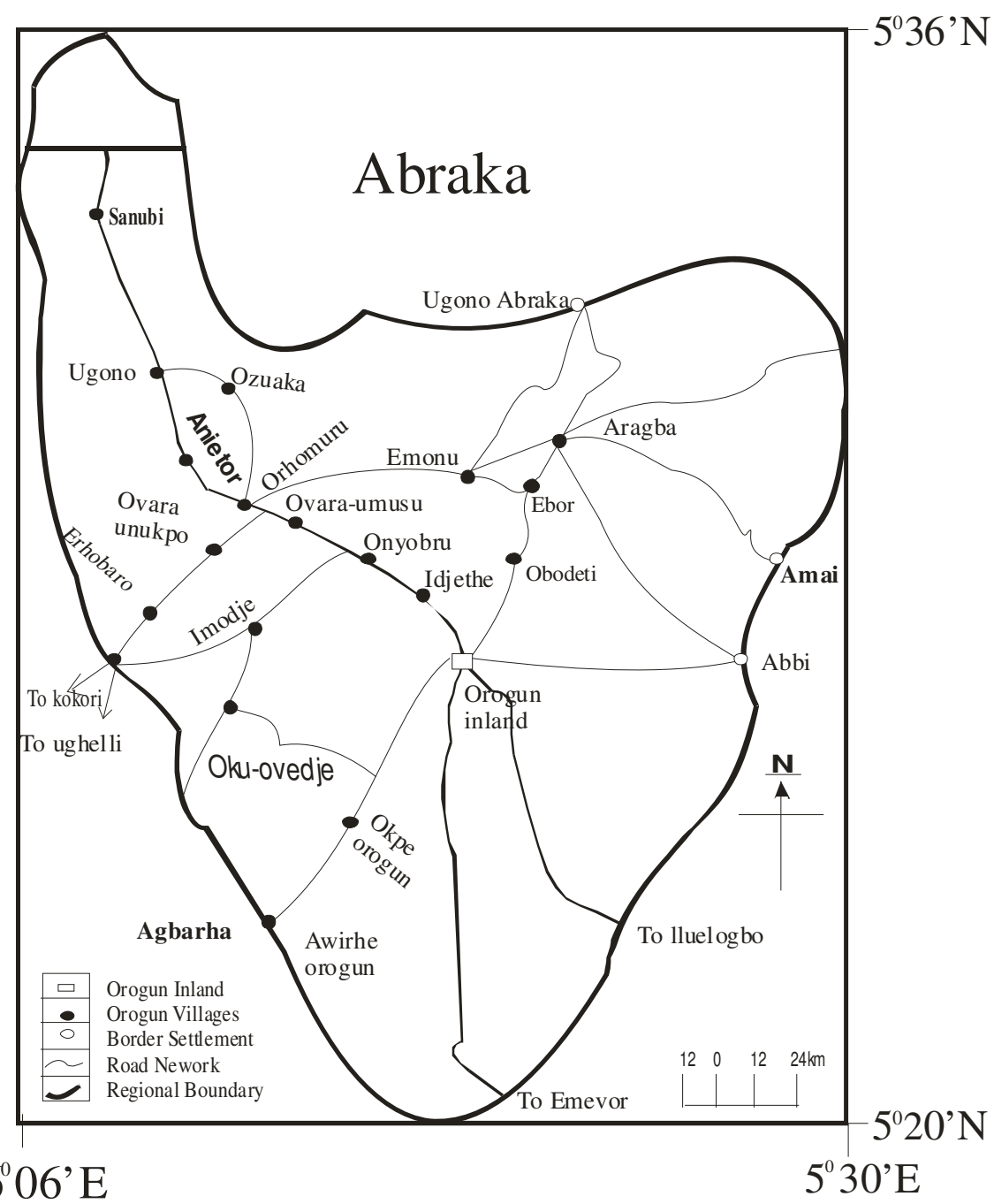

Figure 1 Map of the study area

\section{Materials and Method}

Secondary forests plots of 1,5 and 10 year old, and a mature forest, were selected for study (Ichikogu, 2011). All the secondary forests categories and the mature forest had the same parent material and were selected from comparable flat crestal interfluve sites to ensure that catenary variations in soil properties were minimized. Within each of the secondary forest age categories, ten sample plots of 30 metre square quadrats were 
delimited for investigation. Soil sampling followed the procedure described by Boone et al (1999). Soil samples were collected from five points located randomly within the 30 metre square quadrats at predetermined depths of $0-10 \mathrm{~cm}$ and $10-30 \mathrm{~cm}$. These are referred to as top-soil and sub-soil in subsequent sections.

The approach of sampling from predetermined depths was adopted in order to allow plots to be compared: the thickness of the soil layers varies from place to place. The limit of the top $30 \mathrm{~cm}$ of the soil is chosen for two reasons. Firstly, the limit of the visible humic horizons usually lies here and secondly, numerous observations of root distributions and direct measurement of labeled-phosphorus uptake (Nye and Foster 1960) indicates that in humid regions nearly all the feeding of the annual crops which replace the fallows takes place within this zone. A total of 100 samples of soil were collected from each age category on the basis of 50 samples from topsoil and 50 samples from subsoil. These samples of soil were mixed into 10 composites for each soil depth (on the basis of five samples constituting a composite sample and ten composite samples analyzed for each depth under each secondary forest category) for chemical analysis. The composite samples collected were air-dried, crushed thoroughly mixed and passed through a $2 \mathrm{~mm}$ mesh sieve in readiness for analysis. Weighed sub samples were oven dried so that results for analysis carried out on air dried soils were expressed on the oven dried basis.

Soil nitrogen was analyzed by the Kjeldahl's method. Available phosphorus was determined by leaching the soil with Bray and Kurtz solution $(0.025 \mathrm{M} \mathrm{HCL}$ to $0.03 \mathrm{MN}$ $\mathrm{H}_{4} \mathrm{~F}$ ). The concentration of available phosphorus was determined calorimetrically with "spectronic 20" spectrophotometer after the colour had been developed in soil extract using the ascorbic acid method (Molindo, 2008).

\section{Statistical Analysis}

Analysis of variance tests were used to test whether or not significant differences existed between the secondary forests agecategories and primary forest with respect to soil total nitrogen and available phosphorus content. Where differences exist, post hoc multiple comparisons of means were carried out with the use of the Least Significant Difference (LSD) to check for statistical differences between pairs of secondary forest, and between secondary forests and primary forest.

\section{Results}

Table 1 shows the total nitrogen and available phosphorus content of the topsoil and the subsoil of the different age categories and mature forest. The total nitrogen level in the soil (to a depth of $30 \mathrm{~cm}$ ) increases with increasing forest age. Total nitrogen concentration is highest in the mature forest and least in the 1-year. The mean values of total nitrogen for the 1-year, 5-year and 10year fallows and for mature forest are $0.18 \%$, $0.22 \% 0.34 \%$ and $0.53 \%$ respectively for the topsoil. The corresponding values for the subsoil are $0.11 \%, 0.16 \%, 0.19 \%$ and $0.31 \%$ respectively.

There is a progressive build up of total nitrogen in both the topsoil and the subsoil, though the concentration of total nitrogen is higher in the topsoil than the subsoil (table 1). The differences between all the secondary forest categories in terms of nitrogen concentration of the topsoil are significant.

Similarly the differences between the concentration of total nitrogen in topsoil of the mature forest and each of the secondary forests categories are significant at $p<0.023$ of the least significant differences test. The mean available phosphorus values for the topsoil in $\mathrm{mg} / \mathrm{kg}$ are $4.91,8.81,4.57$ and 11.60 for the 1year, 5-year, 10-year and the mature forest respectively. While the corresponding values for the subsoil are 1.27, 4.53, 1.34 and 5.80 for the 1-year, 5-year, and 10-year fallows and for the mature forest respectively. The trend of available phosphorus concentration in the soil in decreasing order is mature forests $>5$-year old secondary forest $>1$-year old fallow $>10$ year old secondary forest.

The difference among all the age categories and the mature forest taken together is significant at the $0.1 \%$ level of significance of the $\mathrm{F}$ distribution for both the topsoil and the subsoil. The concentration of topsoil 
available phosphorus reached $76 \%$ of the level of concentration of available phosphorus in the mature forest by the fifth year of fallow. The difference between the 1-year old and the 10 -year old secondary forest is not significant at 0.05 level of significance of the least significant differences test while the differences between pairs of the other secondary forest categories on the one hand and between them and the mature forest are significant at 0.0001 significant level of the least significant differences test Compared to the mature forest phosphorus concentration in soil, the 1-year, 5-year and 10-year age categories have less phosphorus in soil than the mature forest.

\section{DISCUSSION}

The pattern of nitrogen concentration in soil is similar to that of its return to the soil through litter fall (nitrogen concentration in litter) and the pattern of increasing soil organic matter with increasing age of fallows. The mean values of soil total nitrogen reported in this study for mature forest are higher than those reported by Aborishade and Aweto (1990) $0.19 \%$, for a rainforest in Gambari Nigeria, Greenland and Kowal (1960), $0.20 \%$ for a mature secondary semideciduous forest in Kade, Ghana, but fall within the range of values reported by Brassell, Unwin and Stocker (1980) for an undisturbed rainforest 'site 1' and 'site 2 ' in North eastern Australia - 0.59\% and 0.45\% respectively for 'site 1' and 'site 2' and by Aweto (1981) for Ijebu-Ode area of southwestern Nigeria $(0.488 \%)$. The mean values reported for the subsoil of the fallows in this study are higher than those reported by Aweto (1981) for fallows following shifting cultivation in south western Nigeria but the topsoil values fall within the range reported by Aweto (1981) and Owusu-Seykere et al. (2006) for a primary forest in Ghana. Both the mean values of the topsoil and the subsoil in this study are higher than the values reported by Feldpausch et al (2010) for forests regenerating from degraded pastures in Manaus central Amazon Brazil.

Though the mean values of total nitrogen in the topsoil are higher than those of the subsoil for the different age categories and the mature forest, there is a progressive build-up of total nitrogen in both the topsoil and the subsoil. The build up of total nitrogen both in the topsoil and the subsoil with forest age can only be partially explained by external inputs. For example, Fernandes et al (1997), Szott et al (1999) reported that nitrogen-fixing plants may contribute $10-15 \mathrm{~kg} \mathrm{ha}^{-1}$ to soils, while Schroth et al (2001) opined that atmospheric deposition may add 5.5-11.5 $\mathrm{kgha}^{-1} \mathrm{yr}^{-1}$ to soil, explaining a fraction of the increasing total soil nitrogen. Another reason for the high soil nitrogen accumulation rates with age may be due to rapid return of nitrogen through litterfall. High subsoil nitrogen concentrations in the fallow may be attributable to leaching from topsoil during the productive life of the rubber, followed by a reduced nutrient capture potential of shallow rooted colonizing secondary vegetation. Mature forest also losses nitrate to the subsoil. Toky and Ramakrishnan (1983) opined that leaching of surface nitrogen can be rapid in oxisols because of the high macro-porosity and hydraulic conductivity. Leaching of surface nitrogen $(0-10 \mathrm{~cm})$ to the subsoil could also explain the increase nitrogen concentration observed in the subsoil with forest maturation. Owusu-Seykere et al. (2006) and Feldspauch et al. (2010), attributed increase nitrogen concentration of subsoil to the leaching of surface nitrogen $(0-10 \mathrm{~cm})$.

The concentration of total nitrogen in the topsoil and the subsoil of this study reached $64 \%$ and $61 \%$ of the mature forest topsoil and subsoil respectively by tenth year. While for a 10 -year fallow following shifting cultivation studied by Aweto (1981) in Ijebu-Ode area of western Nigeria it reached 59\% of that of the mature forest. The differences between all the secondary forest categories in terms of nitrogen concentration of the topsoil are significant. Similarly the differences between the concentration of total nitrogen in topsoil of the mature forest and each of the secondary forests categories are significant at $p<0.023$ of the least significant differences test This indicates that unless deep nitrogen mining with root development occurs, nitrogen losses to the subsoil due to leaching may negatively 
affect surface fertility of soil regenerating from degraded rubber plantation.

Available phosphorus in the soil increased rapidly in the first five years after the abandonment of the plantation, but also declined rapidly from $8.81 \mathrm{mg} / \mathrm{kg}$ to $4.57 \mathrm{mg} / \mathrm{kg}$ by the tenth year. This pattern may be attributed to increasing tree density as age increases during the fallow period with its concomitant relocation of available soil phosphorus from below (soil) to above ground (vegetation) pools. Plants appear to be taking up more soil phosphorus than is available in the 10-year age category due to the high density of trees in the 10-year fallow. The net reduction in soil available phosphorus with increasing forest age, indicates inadequate replacement of available soil phosphorus with plant phosphorus uptake, a trend also observed elsewhere (Johnston et al 2001, Feldpeusch et al 2010). Feldpausch et al. (2010) observed that should this trend continue, phosphorus may become limiting to growth unless other factors such as (a) reduce phosphorus uptake by plants occur (b) increase phosphorus uptake from subsoil occur, or (c) occurrence of the increase in the rate at which unavailable forms of soil phosphorus shift to plant available phosphorus forms to replenish immobilized plant available soil phosphorus.

The findings on phosphorus in this study are in consonance with those reported by Aweto (1981b), Johnston (2001), Lehmann et al (2001a), Feldspauch et al. (2010), but not consistent with those of Toky and Remakrishnan (1983), Angelica and Rafael (2005) whose works on fallows following Slash and burn agriculture show consistent increase in phosphorus with time as against fluctuating pattern of nutrients concentration with time reported in this study. However, the values reported for the concentration of available phosphorus in this study fall within the range reported for the tropical region by Aweto (1981b, 1987), Aborishade and Aweto (1990), Aweto and Iyanda (2003), OwusuSeykere et al. (2006), Molindo (2008) and Aikpokpodion (2011).

\section{Conclusion}

Soil total nitrogen and phosphorus content was higher in the mature forest than the young secondary forest and fallows. The 1-year old fallow and 5-year old secondary forest have higher available phosphorus concentration than the 10-year old secondary forest. Available phosphorus seemed limiting in the secondary forests and the 1-year fallow but with better concentration in the mature forest. Therefore, forests may be encouraged in secondary soils regenerating on degraded rubber plantation to restore the total nitrogen and available phosphorus in the soil, and any attempt at subjecting the 1-year old fallow and the 5-year and 10-year secondary forests to the cultivation of either food or cash crops should involved the use of inorganic fertilizer to increase the available soil phosphorus during the cropping period.

\section{References}

Aborishade, K.D. and Aweto, A.O. (1990). Effects of exotic tree plantation of teak (Tectona grandis) and Gmelina (Gmelina arborea) on forest soil in southwestern Nigeria. Soil use management, 6: 43-45.

Adedeji, F.O. (1983). Nutrient cycles and successional changes following shifting cultivation practice in semi-decidious forests in Nigeria. Forest ecology management, 9: 8799.

Adedeji, O.H. (2008). Nutrient cycling in an agro-ecosystem of rubber plantation in Ikene, southwestern Nigeria; unpublished Ph.D thesis, Department of Geography, University of Ibadan.

Adejuwon, J.O. and Ekanade, O. (1988). A comparison of soil properties under different land use types in a part of the Nigerian cocoa belt. Catena, 15: 319-331.

Angelica, B.C. and Rafael, F.D. (2005). Soil changes during secondary succession in tropical montane cloud forest area. Soil science society of America, 69: 906-914.

Aweto, A.O. (1981a). Organic matter build-up in fallow soils in a part of the forest zone of southwestern Nigeria and its effects on soil properties. Journal of biogeography, 8: 67-74. Aweto, A.O. (1981b). Total nitrogen status of soils under bush fallow in the forest zone of 
southwestern Nigeria. Journal of soil science, 32: 639-642.

Aweto, A.O. (1987a). Vegetation and soils of the savanna enclaves of Urhobo plains, Southwestern Nigeria. Catena, 14: 177-188.

Aweto, A.O. (1987b). Physical and nutrient status of soil under rubber (Heva brasiliensis) of different ages in south western Nigeria. Agricultural systems, 23: 63-72.

Aweto, A.O. (2001). Impact of single species tree plantations on nutrient cycling in West Africa. International journal of sustainable development, world ecology, 8, 356-368.

Aweto, A.O. (2001). Outline geography of Urhobo land in Nigeria. http://www.waado.com.

Bilings, W.D. (1938). The structure and development of old field shortleaf pine stands and certain associated physical properties of the soil. Ecological monographs, 8: 437-499.

Bruijnzeel, L.A and Proctor, J. (1995), 'Hydrology and biogeo-chemistry of tropical montane cloud forest, what do we really know?' P.38-78. In Hamilton et al (ed) Tropical montane cloud forests. SpringerVerlag, Berlin.

Compton, J.A. and Boone E.D. (2000), 'Long term impact of agriculture soil carbon and nitrogen in New England forests' Ecology, 81: 2314-2330.

Deborah, L. and David, F. (2005). Changes in forest biomass, litter dynamics and soils following shifting cultivation in southern Mexico published online.

Efe, S.I. (2006). Regionalization of Nigeria climate: A recent approach: The Nigeria academic forum, 11(3), pp. 32-39.

Ekanade, O.; Adesina, F. and Egbe, N. (1991). Sustaining tree crop production under intensive land use: An investigation into soil quality differentiation under varying cropping patterns in western Nigeria. Journal of environmental management, 32: 105-113.

Feldpausch, T. R., Rondon, M.A. Fernandes, E.C.M S. Riha, R.J. and Wandelli, E. (2004) Carbon and nutrient accumulation in secondary forests regenerating on pastures in central Amazonia. Ecol. Appl., 14, 164-176.

Feldpausch, T.R. Susan, J.R. Fernandes E.C.M. Wandelli, E.V. (2005). Development of forest structure and leaf area in secondary forests regenerating on abandoned pastures in Central Amazonia. Earth interactions. 9 paper number 6.

Feldpausch, L.; Lawrence, W.F.P. and Johnson, D.W. (in press). Forests regenerating from pastures in Amazonia. Ecological applications, 66, 111-122

Hughes, R.F.; Kauffman, J.B. and Jaramillo, V.J. (1999). Biomass, carbon and nutrient dynamics of secondary forest in a humid tropical region of Mexico. Ecology, 80: 18921907.

Galindo, J.L.; Gonzalez, E.; Quintana, P. and Garcia (2002). Tree composition and structure in disturbed stands with varying dominance by pinus species in the highlands of Chiapas, Mexico. Plant ecology, 162: 259-272.

Ichikogu, V.I. (2011). Organic matter dynamics in soils regenerating on degraded abandoned rubber plantation in Orogun area of the rainforest zone of Southern Nigeria

Johnston, C.M.; Veira, I.C.G.; Zarim, D.J.; Frizano, J. and Johnson, A.H. (2001). Carbon and nutrient storage in primary and secondary forests in eastern Amazonia. Forest ecology and management, 147: 245-252.

Juo, A.S. and Lai, R. (1977). The effect of fallow and continuous cultivation on the chemical and physical properties of an alfisol in the tropics. Plant and soil, 47: 567-584.

Kowal, J. M. L., and Tinker, P. H. B. (1959). Soil changes under a plantation established from high secondary forest. J. west Afri. Insti. Oil Palm Res., 4, 66-81.

Loudelout, H. and Meyer, J. (1954). Mineral element and organic material cycles in the equatorial forest of the Congo. Occeologia planetarium, 7: 1-21.

Marrs, H.R. (1996). Soil fertility and nature conservation in Europe theoretical considerations and practical management solution. Advance ecology research, 24: 241300.

Molindo, W.A. (2008). Determination of the nutrient status of soil after incubation with organic residues for different days in Benin City, Nigeria. World journal of agricultural sciences, 4(6): 731-736.

Molindo, W.A.; Usifo, A.E. and Akoma, O.C. (2009). The physiochemical analysis of an 
utisol polluted with different petroleum products, treated with poultry droppings and planted with maize in Benin City, Nigeria. Ethiopian journal of environmental studies and management, 2(2). 58-66.

Nye, P.H. and Hutton, R.G. (1957). Some preliminary analysis of fallows and cover crops at West African institute for oil palm research Benin. Journal of West African institute for oil palm research, 2: 237-243.

Nye, P.H. and Greenland, D.J. (1959). Increase in the carbon and nitrogen contents of tropical soils under natural fallows. Journal of soil science, 10: 284-299.

Nye, P.H. and Foster, W.N.M. (1960). The relative uptake of phosphorus by crops and natural fallow from different part of their roots zone. Journal of agricultural science, 26: 148159.

Ogunkunle, A.O. and Eghaghara, O.O. (1992). Influence of land use on soil properties in a forest region of southern Nigeria. Soil use management, 8: 121-125.

Owusu-Seykere, E. Cobbina J. and Wakatsuki T. (2006). Nutrient cycling in primary, secondary forests and cocoa plantation in Ashanti Region, Ghana. West Africa journal of applied ecology, volume 9 (Jan-Jun) paper 10 of 18

Post, W.M. and Kwon, K.C. (2000). Soil carbon sequestration and land use change: Processes and potential global change. Biology, 6: 317-327.
Toky, O.P., and Ramakrishnan, P.S (1983). Secondary succession following slash and burn agriculture in north-eastern India II: Nutrient cycling. Journal of ecology, 71: 746753.

Schroth, G.; Elias, M.E.A.; Uguen, K.; Seizas, R. and Zech, W. (2001). Nutrient fluxes in rainfall, throughfall and stemflow in treebased land use systems and spontaneous tree vegetation of central Amazonia. Agriculture ecosystems and environment, 87: 37-49.

Santana, M.B.M., Rosand, F.R.C. and Vasconcelos, F.A.P. (1977). Fertility of soils used for rubber in southern Bahia and degree of tolerance of this crop to aluminium. Revista Theobroma (Brazil), 7, 125-132.

Silver, W.L., Ostertog, R. and Lugo, A.E. (2000). The potential for carbon sequestration through reforestration of abandoned tropical agricultural pasture lands. Restoration ecology, 8: 394-407.

Szot, L. Fernandez, E.C.M and Sanchez, P.A. (1991), 'Soil-plant interactions in agro forestry systems' Forest Ecology and Management, 45: 127-152.

Tinker, P.H.B. (1963). Changes occurring in the sedimentary soil of southern Nigeria after oil palm establishment. J. west Afri. Insti. Oil Palm Res., 4, 66-81.

Table 1 Concentrations of total (nitrogen in \%) and available phosphorus (in $\mathrm{mg} / \mathrm{kg}$ ) in topsoil (0$10 \mathrm{~cm})$ and subsoil $(10-30 \mathrm{~cm})$ at various stages of secondary forests regeneration from degraded abandoned rubber (Hevea brasiliensis) plantation; Values are mean of $\mathrm{n}=10$

\begin{tabular}{llllllllll}
\hline & \multicolumn{2}{c}{ Topsoil } & \multicolumn{2}{c}{ AGE CATEGORIES } & \multicolumn{2}{c}{ Topsoil } & \multicolumn{2}{c}{ Subsoil } & \multicolumn{2}{c}{ Subsoil } \\
\hline Soil properties & 1-year & 5-year & 10-year & Forest & 1-year & 5-year & 10-year & Forest \\
& & & & & & & & & \\
Total nitrogen & 0.18 & 0.22 & 0.34 & 0.53 & 0.11 & 0.16 & 0.19 & 0.31 \\
$\begin{array}{l}\text { Available } \\
\text { phosphorus }\end{array}$ & 4.91 & 8.81 & 4.57 & 11.60 & 1.27 & 4.53 & 1.34 & 5.80 \\
\hline
\end{tabular}


Table 2 Summary of the results obtained by analysis of variance for topsoil total nitrogen and available phosphorus

\begin{tabular}{llllllll}
\hline Parameter & $\begin{array}{l}\text { Source of } \\
\text { variation }\end{array}$ & $\begin{array}{l}\text { Sum of } \\
\text { squares }\end{array}$ & DF & MSE & F Value & $\begin{array}{l}\text { Probability of } \\
\text { F }\end{array}$ & Decision \\
\hline $\begin{array}{l}\text { Total } \\
\text { nitrogen }\end{array}$ & $\begin{array}{l}\text { Between } \\
\text { samples }\end{array}$ & 0.73 & 3 & 0.24 & 132.94 & 0.0000 & Significant \\
& $\begin{array}{l}\text { Within } \\
\text { samples }\end{array}$ & 0.07 & 36 & 0.002 & & & \\
Available \\
phosphorus & $\begin{array}{l}\text { Between } \\
\text { samples }\end{array}$ & 377.64 & 3 & 125.88 & 8.49 & 0.0000 & Significant \\
& & & & & & \\
\hline & $\begin{array}{l}\text { Within } \\
\text { samples }\end{array}$ & 5.63 & 36 & 0.16 & & & \\
\hline
\end{tabular}

Table 3: Summary of the results obtained by analysis of variance for subsoil total nitrogen and available phosphorus

\begin{tabular}{|c|c|c|c|c|c|c|c|}
\hline Parameter & $\begin{array}{l}\text { Source of } \\
\text { variation }\end{array}$ & $\begin{array}{l}\text { Sum of } \\
\text { squares }\end{array}$ & $\overline{\mathrm{DF}}$ & MSE & F Value & $\begin{array}{l}\text { Probability of } \\
\text { F }\end{array}$ & Decision \\
\hline \multirow[t]{2}{*}{$\begin{array}{l}\text { Total } \\
\text { nitrogen }\end{array}$} & $\begin{array}{l}\text { Between } \\
\text { samples }\end{array}$ & 0.21 & 3 & 0.07 & 35 & 0.0001 & Significant \\
\hline & $\begin{array}{l}\text { Within } \\
\text { samples }\end{array}$ & 0.08 & 36 & 0.002 & & & \\
\hline \multirow[t]{2}{*}{$\begin{array}{l}\text { Available } \\
\text { phosphorus }\end{array}$} & $\begin{array}{l}\text { Between } \\
\text { samples }\end{array}$ & 3.04 & 3 & 1.01 & 16.83 & 0.0001 & Significant \\
\hline & $\begin{array}{l}\text { Within } \\
\text { samples }\end{array}$ & 2.06 & 36 & 0.06 & & & \\
\hline
\end{tabular}

